\title{
La Ficción Climática en la nueva narrativa hispánica
}

\author{
David García Ponce ${ }^{1}$
}

Como citar esta reseña: García Ponce, D. (2021). La Ficción Climática en la nueva narrativa hispánica, Pangeas. Revista Interdisciplinar de Ecocrítica (núm. 3) 94-96. https://doi.org/10.14198/ PANGEAS.19181

Desde que en los años noventa se acuñara el término de ecocrítica, este enfoque ha seguido una trayectoria sólida en la crítica literaria. Cada vez son más los estudios que recurren a ella para indagar en la relación entre literatura y naturaleza y los posibles diálogos que surgen de estas dos variables. En este contexto, señalaríamos los problemas derivados de la crisis medioambiental, los escándalos desatados por malas praxis empresariales y/o políticas. A todo ello, debemos añadir el conjunto de actores que, por un lado, han sensibilizado a la sociedad y, por otro, han contribuido a ficcionalizar tales acciones. Como consecuencia de ello, en las dos últimas décadas, principalmente en el ámbito anglosajón, han surgido diferentes ramas de la ecocrítica que reformulan la representación de la naturaleza en la literatura. Este sería el caso de la nature writing, que se fundamenta en la contemplación de la naturaleza, un aspecto que, por lo general, había estado reservado a la poesía. En lo que a narrativa se refiere, la ficción climática o climate fiction (ya conocida como Cli-Fi) ha consolidado un espacio en la novela y en el cuento.

Hasta hace relativamente pocos años, la representación de las catástrofes y los desafíos naturales quedaban circunscritos al ámbito de la ciencia ficción, en unos escenarios distópicos y apocalípticos. En menor proporción, el género del ensayo trataba de hallar una explicación científica de los hechos. Sin embargo, se ha producido un viraje en la representación de los fenómenos medioambientales en la literatura más reciente.
Si hablamos de giro espacial (spatial turn), el giro afectivo o incluso el giro lingüístico para referirnos a las nuevas tendencias en los estudios culturales, no podemos obviar la nueva construcción del discurso medioambiental en la literatura. Estas nuevas direcciones cuestionan el origen de los hechos y los responsables. En lo que a literatura se refiere, el relato actual se forja con una interrelación de variables de índole humanística (demografía, ecología, economía, geografía, etc.). Con este diálogo, el autor busca, a través de mecanismos de ficción, la mejor forma de conjugar crítica y estética, mientras despierta una conciencia ecológica. Dicho sea de otro modo, hemos pasado de la función contemplativa de la literatura al activismo, y de la visión fantástica de los hechos al estudio holístico del fenómeno medioambiental. En este contexto nace la Ficción Climática.

Estío. Once relatos de ficción climática de la editorial Episkaia reúne a siete autoras y cuatro autores: María Bonete, Eva Cid, Aixa de la Cruz, Layla Martínez, Merche Montero, Cristina Morales, Alejandro Morellón, Aroa Moreno Durán, Richard Parra, Carlos Pérez y Francisco Serrano. Once firmas de escritores nacidos en el último cuarto del siglo XX que, en esta obra, tienen en común la incursión en temas poco transitados en la prosa. Ellos comparten diferentes registros y estéticas unidos bajo un mismo paraguas temático: cuestiones de índole medioambiental, con especial relevancia la presencia de las catástrofes naturales. Estos jóvenes literatos no

1. David García Ponce. Universidad de Huelva. davidgponce@gmail.com https://orcid.org/ 0000-0002-8745-7083

Reseña de: AA.VV. Estío. Once relatos de ficción climática. Madrid: Ed. Episkaia, 2019. ISBN: 978-84-949223-0-5. 212 pp. 
solo recrean nuevos temas, que tradicionalmente habían pasado de cuclillas por la narrativa española, sino también calibran la eficacia de la literatura para representar problemas relacionados con la ficción climática.

Por la obra pasan seres extraños. En Lunes, María Bonete, nos sitúa en un escenario inundado en el cual han aparecido monstruos que la población local acaba aceptándoles con indiferencia. Otras veces, el ser humano debe enfrentarse a las dificultades que plantea el cambio climático. Es el caso de Nómadas de Eva Cid que nos ubica en un mundo ya destruido y en el cual el hombre debe aprender a sobrevivir en un paisaje desértico. Un caso similar describe Alejandro Morellón en Mi Dios es hambre. En un fragmento del cuento leemos: "He aquí un no lugar" (2019: 65), un recurso para describir un entorno totalmente seco y sin vida. Tampoco faltan los enclaves misteriosos. En Alexandría de Merche Montero, asistimos a un relato de aventuras donde la protagonista accede a una antigua biblioteca en un antiguo espacio verde desaparecido. El Resort de Layla Martínez describe un centro vacacional artificial dentro de treinta años, donde las sensaciones naturales se consiguen por ilusiones ópticas y espacios tridimensionales que, sin embargo, sumergen al lector en una atmósfera de opresión. Otros autores ahondan en las relaciones humanas en un clima de catástrofe natural: Francisco Serrano incluye en Inundación dosis de sexo y violencia y Aroa Moreno Durán en La gravedad narra la relación de una pareja en un clima caluroso.

Sorprende comprobar como dos autoras que actualmente cuentan con un reconocimiento por parte de la crítica se hayan adaptado al cometido de esta obra aunque ello les suponga emplear un registro diferente al habitual. Es el caso de Atardecer nuclear de Cristina Morales y Aixa de la Cruz con Amaiur. La primera describe en su relato unos atardeceres aparentemente bellos y que, sin embargo, sus tonalidades son el resultado de la contaminación. Sorprende como en clave poética se puede alertar de los cambios que sufre nuestro planeta, provocados por la polución ambiental. Con un tono similar, Aixa de la Cruz dialoga con su propio cuerpo.

Por el número de autoras que participan y las protagonistas de los cuentos se comprueba que destaca la voz femenina, y es que en la lectura de estos textos fluye el ecofeminismo, otra de las ramas de la ecocrítica. Este enfoque convive perfectamente con los principios de la ficción climática, con la salvedad de que centra la atención en el rol que desempeña la mujer en la naturaleza. El ecofeminismo aborda las luchas contra el heteropatriarcado, el papel de la mujer en la toma de decisiones medioambientales y las responsabilidades que la mujer, como sujeto autónomo, tiene en el uso nocivo de los recursos naturales.

El compendio demuestra como las voces críticas de nuestra narrativa son capaces de hacer de una catástrofe natural o de un testimonio de mala praxis, materia literaria adaptada a diferentes paradigmas, desde una situación fantástica hasta una escena en clave realista. Los relatos nos sitúan en una pluralidad de escenarios -desiertos, paisajes inundados, escenarios con bacterias letales, etc.- que plantean especulaciones sobre la vida en el planeta en un futuro no muy lejano, expresado con estilos literarios diferentes.

Una lectura rápida nos puede precipitar a la conclusión de que a estos autores les une un pesimismo, sin embargo, conviene matizar esto último. Los personajes que pueblan los escenarios distópicos, reaccionan ante las catástrofes climáticas y buscan tanto responsables como respuestas, lo cual debe interpretarse como un hilo de esperanza.

La obra concluye con un epílogo de Yayo Herrero, antropóloga y referente en el ecologismo español. La autora se lamenta del retraso en la concienciación: "una gravísima desestabilización global de los ecosistemas y ciclos naturales con desastrosas consecuencias" (2019: 194) pero, como al resto de autores, no le falta una dosis de optimismo: "Vale mucho la pena embarcarse en esta tarea. Hacen falta todos los lenguajes: los de la ciencia, política y economía y también los artísticos y literarios" (2019: 197).

En definitiva, este conjunto de cuentos dedicados a la ficción climática, además de aportar una lectura entretenida y sin prolegómenos, nos invita a la reflexión sobre el cambio climático y sus consecuencias. En este contexto, la literatura contribuye con lecciones de optimismo a imaginar formas de vida más justas y sostenibles. Con la lectura de esta obra, un lector sensibilizado puede encontrar un estímulo para bucear en esta temática. 
Se trata de una literatura que pasa a la acción, recordando las palabras de Glen Love, allá por los años noventa, en The ecocriticism reader, una de las obras fundacionales de la ecocrítica: "la función de la literatura es redireccionar la conciencia humana hacia una consideración total de su importancia en un mundo natural amenazado [...] reconociendo la supremacía de la naturaleza y la necesidad de crear una nueva ética y estética" (1998: 62).

\section{BIBLIOGRAFÍA}

AA.VV. (2019). Estío. Once relatos de ficción climática. Madrid: Ed. Episkaia.

GLOTFELTY, G., FROMM, H. Glotfelty. (1996). The Ecocriticism Reader. Landmarks in Literary Ecology. London: The University of Georgia Press.



